booklet indicates concisely the characteristics and value of contract research for industry. Emphasis is laid on the importance of determining the areas in which outside research facilities promise to be most useful and also the facilities, experience and talent which the research institute can apply in these areas. The way in which these two are related may vary considerably. A further booklet, Group Research, also issued by the Battelle Memorial Institute, describes the nature of the group research projects conducted by the Institute during more than thirty years, their conduct and administration and the general advantages of such research, as well as the contribution which a research institute can offer to this type of co-operative research. Stress is laid on the value of the objective approach which such an institute can bring, and it is claimed that outside research organization with experience of group research can define and analyse problems effectively, nominate potential research approaches and formulate programmes which take account of technical, economic and social aspects.

\section{Training Guide, 1963}

THE Training Guide, 1963, published by the Royal Institute of Chemistry, gives details of qualifications and courses, grants and scholarships, and firms sponsoring sandwich courses for students in chemistry (Pp. ii +36 . London: Royal Institute of Chemistry, 1963. 2s.6d.). Lists of universities and colleges offering full-time degree courses in chemistry as well as of technical colleges offering full-time, sandwich or part-time courses leading to qualifications in chemistry or applied chemistry are also included.

\section{Index to Current Periodicals received in the Library of the Royal Anthropological Institute}

THE library of the Royal Anthropological Institute receives more than 470 current periodicals connected with every branch of anthropology. Now an index to these periodicals is being prepared under various headingsphysical anthropology, archæology, cultural anthropology, ethnography and linguistics (1, Part I; January-March, 1963. Subscription $40 s$. por annum, four parts). Copies can be obtained from the Librarian of the Royal Anthropological Institute, 21 Bedford Square, London. The production of periodical literature has so increased in recent years as to make it almost impossible to keep track of what has appeared. The Indexes of the Royal Anthropological Institute will prove of real use to students in the various branches of anthropology and will meet a very pressing need.

\section{Black Soils of India}

The regur soils (meaning sticky black earth) of India, also called black cotton soils, have excited a good deal of interest among soil scientists, because of their extent, economic importance and characteristic properties. A recent publication summarizes the information available (66 references) and is illustrated by several maps and photographs showing the location, vegetation and profiles of these soils (Black Soils of India. By S. P. Raychaudhuri, B. B. Roy, S. P. Gupta and M. L. Dewan. Pp. iv +47. Now Delhi : National Institute of Sciences of India, 1963). They cover an area of about $800,000 \mathrm{sq} . \mathrm{km}$. of the Deccan peninsula. The climate is monsoon, the average annual temperatures being $20^{\circ} \mathrm{C}$ in December and $30^{\circ}-35^{\circ} \mathrm{C}$ in May; the average rainfall is between 500 and $1,000 \mathrm{~mm}$, mostly from June until September. The natural vegetation is tropical dry deciduous and tropical thorn forest, the dominant specios being Anogeissus latifolia, Terminalia tomentosa and Acacia catechu. The parent material of the soils is mainly Deccan trap, alluding to the step-like aspect of basaltic rocks, of the Cretaceous period; the black soils are found not only on the volcanic plateau but also on transported material derived from the trap and on other formations of basic character. The typical black soil on flat or gently undulating ground may be several metres deep without zoning; it is shallower and not so dark in colour on slopes. It is slightly alkaline, low in organic matter - the porcentage of carbon being about 0.5 --but contains, on the average, 50 per cent clay and has a high cation exchange capacity saturated mainly with calcium and magnesium. The chief clay mineral is montmorillonite. It shows great expansion and shrinking on wetting and drying; the aggregates are stable, the permeability is good. Cotton, jowar, ground-nut and wheat are the important crops, and also sugar cane if irrigation is possible. These soils are placed in the world group of black soils of the tropics and subtropies ('grumusols').

\section{Announcements}

Srr Edward Playfarr, chairman of International Computers and Tabulators Ltd., has been appointed president of the British Computer Society in succession to Mr. R. L. Michaelson. Sir Edward is a governor of the Imperial College of Science and Technology, a member of the boards of Westminster Bank Ltd., Westminster Foreign Bank Ltd., and Glaxo Laboratories Ltd., and is also a member of the Royal Fine Arts Commission. He has held various Government positions.

THe "Polarmeeting 1963" of the German Society of Polar Research will be held in Karlsruhe during October 69. Further information can be obtained from Karl-Heinz Tiedemann, $23 \mathrm{Kiel}$, Eckernforder Strasse 1.

A ONE-DAY symposium on "Food Supply and Nature Conservation" will be held at the Cambridgeshire College of Arts and Technology on November 2. Further information can be obtained from Dr. R. I. B. Cooper, Cambridgeshire College of Arts and Technology, Collier Road, Cambridge.

A MEETING of the Photoelectric Spectrometry Group on "Reflectance Spectroscopy" will be held at the Imperial College of Science and Technology, London, on October 25. Further information can be obtained from the Honorary Secretary, the Photoelectric Spectrometry Group, Unicam Instruments Ltd., York Streot, Cambridge.

THE Technicon Instruments Company's third annual symposium, entitled "Automated Chemical Analysis and Automated Analytical Techniques", will be held during November 5-6 at the Royal College of Surgeons, Lincoln's Inn Fields, London. Further information can be obtained from the Technicon Instruments Co., Ltd., Hanworth Lane, Chertsey, Surrey.

The Institute of Physics and the Physical Society has announced that its 1964 Exhibition of Scientific Instruments and Apparatus will be held in the Halls of the Royal Horticultural Society, Vincent Square, London, S.W.1, during January 6-9, 1964. The 1965 Exhibition will be held in the first week of April in the Manchester College of Science and Technology.

An international Solar Symposium will be held at the University of Sydney, under the auspices of the Australian Commonwealth Scientific and Industrial Research Organization and the University of Sydnoy, during November 12-15. Its purpose is to roview present-day solar research, to discuss plans for the forthcoming solar cycle and to consider the problems of postgraduate training in astrophysics. Further information can be obtained from the Organizing Committee, Solar Symposium, Radiophysics Division, C.S.I.R.O., University Ground, City Road, Chippendale, Sydnoy, N.S.W., Australia.

ERRATUM. In the seventh paragraph of the article entitled "Decomposition of Alkali Metal Nitrates by Light Ions of Kilovolt Energy", by Dr. S. R. Logan, which appeared on p. 369 of the July 27 issue of Nature, " $34 \mathrm{eV}$ amp" and " $10 \mathrm{eV} / \mathrm{amp}$ " should read $34 \mathrm{eV} / \AA$ and $10 \mathrm{eV} / \AA$ respectively. 